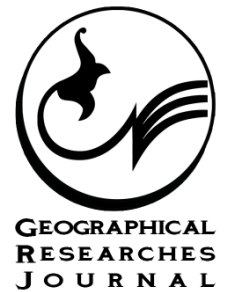

\title{
Simulation of Climatic Conditions within the Caves Through a Controlled Laboratory Environment to Estimate the Annual Dissolution Rate of Karstic Shapes Inside Katale Khor and Saholan Caves
}

\section{A R T I C L E I N F O}

\section{Article Type}

Original Research

\section{Authors}

Rezaei Moghaddam MH. ${ }^{1} P h D$,

Karimi Soltani P. ${ }^{2} \mathrm{PhD}$,

Abdolmaleki T: ${ }^{* 1} M A$
Mokhtari D. ${ }^{1} \mathrm{PhD}$

A B S T R A C T

Aims \& Backgrounds Katlekhour Cave near Garmab (Zanjan) and Saholan Cave in southeast Mahabad, two Iranian tourist caves, attract a large number of tourists annually. Indiscriminate entry and higher number of tourists into the fragile and sensitive environment of the caves increase the concentration of carbon dioxide and disturb the chemical equilibrium inside the cave and it also has devastating effects, like erosion and corrosion, on Karst forms inside the cave. Therefore, this paper attempts to investigate the annual dissolution rate of cave forms by simulating and reconstructing climatic conditions inside a controlled laboratory environment.

Methodology To achieve the objectives of the study, data on temperature, relative humidity and CO2 content within the caves in question during two 15-day periods in February due to low number of tourists and April due to high tourist presence inside the caves were collected using triple tool of temperature, humidity, and Co2 gauge model (AZ 77535). Next, by simulating the same conditions in a controlled laboratory environment, the amount of annual dissolution of the forms inside the caves was calculated using weighting method.

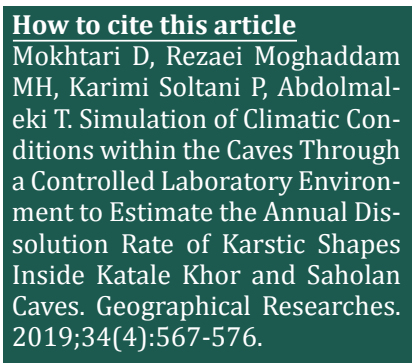

Findings The amount of dissolution and scaling of forms is $0.9445 \mathrm{~g} /$ year for Katlekhour and $2.20 \mathrm{~g} /$ year for Saholan Cave. Of this amount, $0.7661 \mathrm{~g}$ is $81.12 \%$ of total dissolution for Katlekhour Cave and $1.6991 \mathrm{~g}$ is $84.45 \%$ for Saholan Cave are attributed to tourists' presence.

Conclusion Maximum presence of tourists in Katlekhour and Saholan Caves caused the micro-climates in which the increased level of the concentration of de-carbohydrate increases the temperature of cave and decreases the moisture. As a result of these changes, the formation process of karstic shapes within the caves is disrupted, resulting in the destruction and shattering of the forms.

Keywords Cave Climatic Simulation; Cave Tourism; Saholan Cave; Katalekhour Cave

\section{I T A T I O N L I N KS}

\begin{abstract}
[Ahmadi \& Khoshraftar; 2011] Evaluation of geotourism capabilities of katalekhor cave in Zanjan using the techniques SWOT; [Asghari Moghaddam, et al; 2006] Studying of geomorphology, geology and genesis of Sahoolan water cave northwest of Iran; [Baker; 2014] The jenolan environmental monitoring program; [Baldini, et al; 2006] Carbon dioxide sources, sinks, and spatial variability in Shallow temperate zone caves: Evidence from Ballynamintra cave Irelands; [Behniyafar \& Qanbarzadeh; 2016] Karst geomorphology: Processes, forms and management of karst environments; [Calaforra, et al; 2003] Environmental control for determining human impact and permanent visitor capacity in a potential show cave before tourist use; [De Freitas; 2010] The role and importance of cave microclimate in the sustainable use and management of show caves; ['Sebela, et al; 2013] Impact of peak period visits on the Postojna cave (Slovenia) microclimate; [Ek \& Gewelt; 1985] Carbon dioxide in cave atmospheres. new result in belgium and comparison with some other countries; [Gillieson; 2005] Caves, processes, development, management; [Hutacharern; 2004] The effects of human impacts on cave and karst Biodiversity: Thailand Component; [Karimi Soltani \& Rezaei; 2015] Daily and monthly fluctuation of carbon dioxide in Ali-Sadr cave of Hamedan and tourists' health; [Lang, et al; 2016] Carbon dioxide seasonality in dynamically ventilated caves: The roles of modes and advective fluxes; [Lang, et al; 2017] A show cave management: Anthropogenic $\mathrm{CO} 2$ in atmosphere ofV'ypustek cave; Moravian karst, Czech Republic); [Linan, et al; 2008] Carbon dioxide concentration air within the Narja cave (Malaga, Andalusia, Spain); [Maleki, et al; 2015] The role of the tourists in the karst dissoiution of the secondary shapes inside caves, case study: Hamedan Ali-Sadr cave; [Maleki \& Karimi Soltani; 2015] Tourists and their role in microclimatic changes inside the caves case study: Ali-Sadr cave (Hamedan, Iran); [Maleki, et al; 2014] Tourists and their role in microclimatic changes inside the caves case study: Ali-Sadr cave (Hamedan, Iran); [Michie; 1997] An investigation of the climate, carbon dioxide and dust in Jenolan caves, N.S.W; [Mokhtari; 2015] Geotourism; [Moroni; 2013] Radon and carbon dioxide monitoring as approach to touristic exploitation of caves; [Rezaei \& Nakhaei; 2008] Spleogenesis of Katalehkhor cave in Zanjan province; [Song, et al; 2000] The influences of cave tourism on $\mathrm{CO} 2$ and temperature in

Baiyun cave, Hebei, China
\end{abstract}

\section{Correspondence}

(1) No. 44, Karami Alley Code: 1841873177

Phone: +98 (21) 55902186

Fax: +98 (21) 55902186

ta.abdolmaleki@gmail.com

\section{Article History}

Received: January 26, 2019

Accepted: November 2, 2019

ePublished: December 11, 2019 
محيط غارها به سبب طبيعت بستهاى كه دارند بدون حضور و دخل

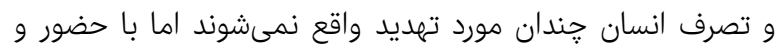
دخل و تصرف انسان اين اكوسيستمهاى طبيعى مورد تهديد تهريد قرار

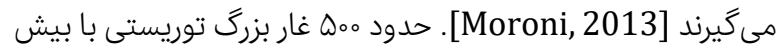

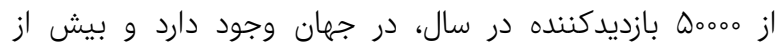

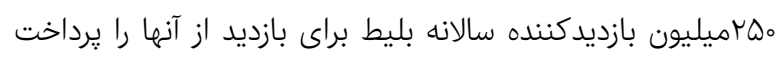

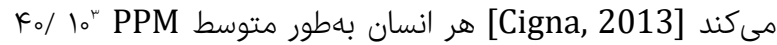

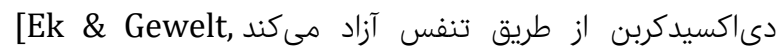

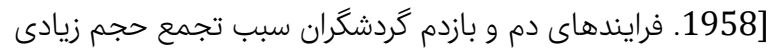

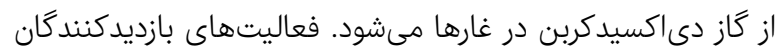

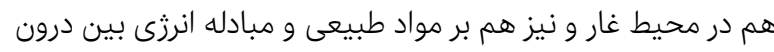

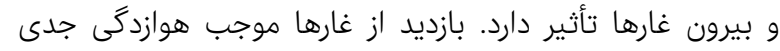

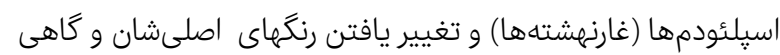
اوقات بهطور كامل آسيب ديده يا تخريب مى اسشوند [Song, 2000]

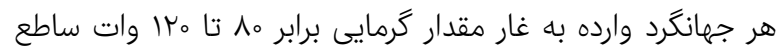

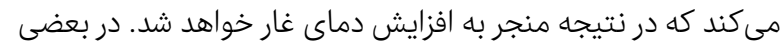

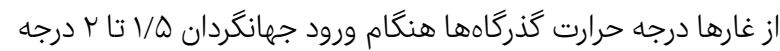
سانتى

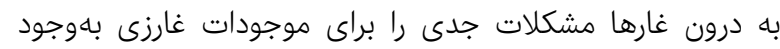

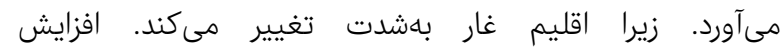

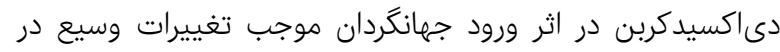
فرايند انحلالى خواهد شد. زيرا غلظت

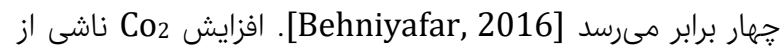

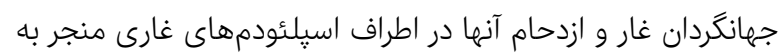
تجزيه آنها خواهدشد. عبور سياحان از غار آنار آلتاميرا (Altamira)،

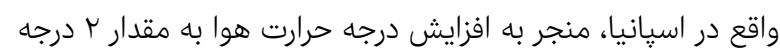

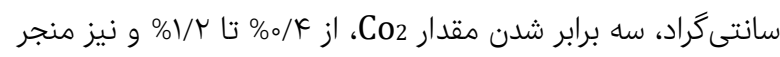

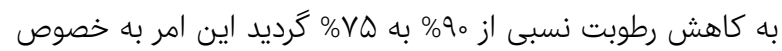

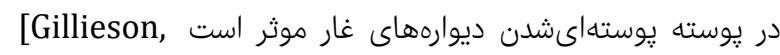

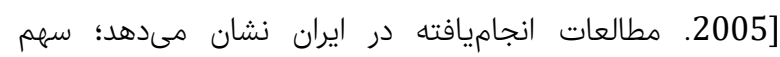

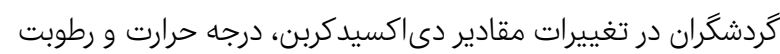

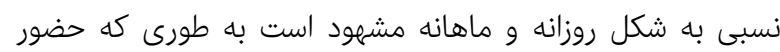
كَردشكران در غار عليصدر همدان و فعاليت دم و بازدم آنها مقادير ماند

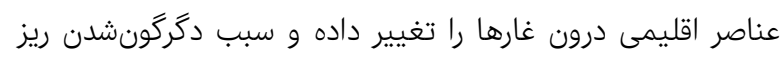

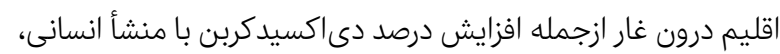

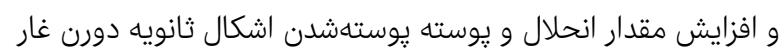
[Maleki, 2015; Maleki, 2014, karimi عليصدر شده استان

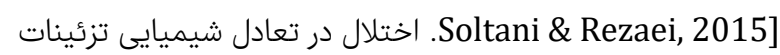

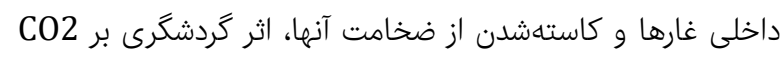

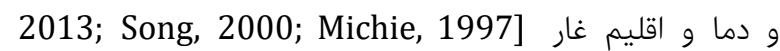
[Baker, 2014; [مebela,

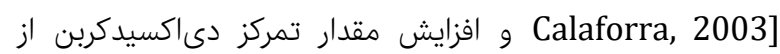

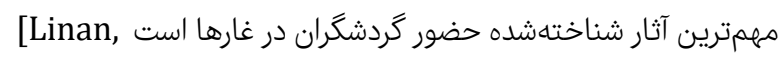
[2008. نقش و اهميت ريز اقليم غار در استفاده يايدار و مديريت
شبيهسازى شرايط اقليمى درون غارها در محيط آزمايشگاهى كنترل شده، جهت برآورد مقدار انحلال سالانه اشكال كارستى درون غارهاى كتلهخور و

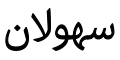

PhD داود مختارى كروه زئومورفولوزى، دانشكده برنامهريزى و علوم محيطى، دانشكاه تبريز، تبريز، ايران

Pحمدحسين رضايى مقدم PhD كروه زئومورفولوزى، دانشكده برنامهاريزى و علوم محيطى، دانشكاه تبريز، تبريز، ايران

PhD يمان كريمى سلطانى كروه جغرافيا، دانشكده ادبيات و علونى علوم انساني، دانشكاه رازى كرمانشاه، ايران

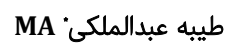
گروه زئومورفولوزى، دانشكده برنامهريزى و علوم محيطى، دانشكاه تبريز، تبريز، ايران

جكيده اهداف و زمينهها: غار كتله خور در نزديكى شهر گرماب (زنجان) و غار سهولان در

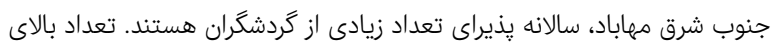

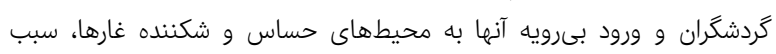

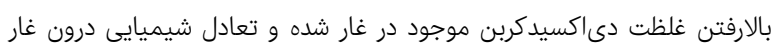

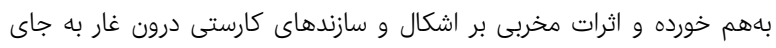

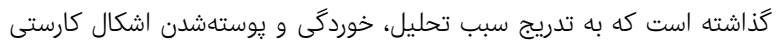

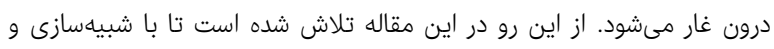

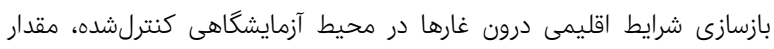

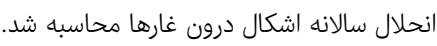

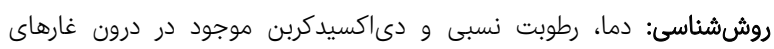

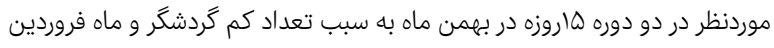

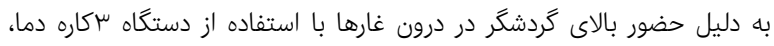

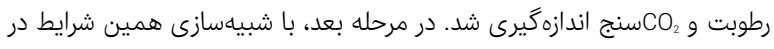

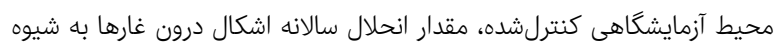
وزنى محاسبه كرديد.

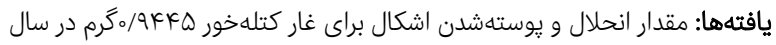

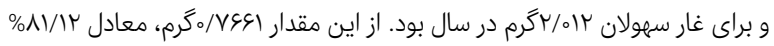
كل انحلال براى غار كتله خور و و سهم كردشكران بود. نتيجه گيرى: ورود حداكثرى كَردشَران به درد درون غارهاى كتلهخور و سهولان،

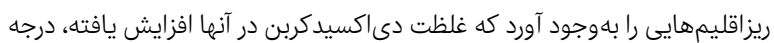

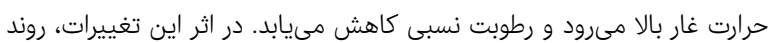

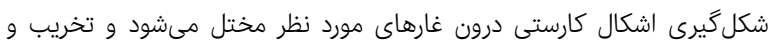
شكستهشدن اشكال را به دنبال دارد. كليدوازهها: شبيهسازى اقليمى غارها، كَردشَرى در غارها، غار سهولان، غار كتلهخور

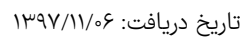

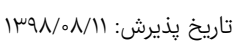
ta.abdolmaleki@gmail.com : نويسنده sسئول: بإيرش:

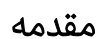
غارها از جمله اشكال زئومورفولوزيكى حساس و شكننده هستند. 
شبيهسازى شرايط اقليمى درون غارها در محيط آزمايشكاهى كنترل شده، جهت برآورد مقدار انحلال...

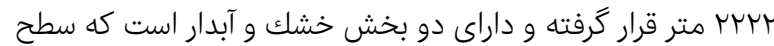

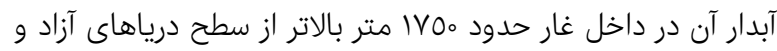

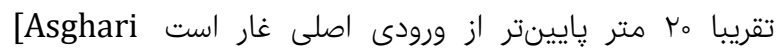

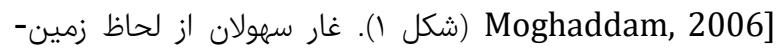

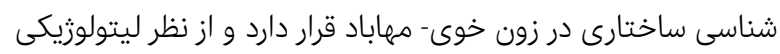

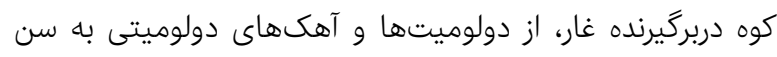

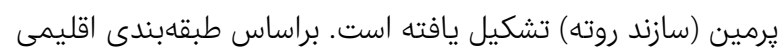

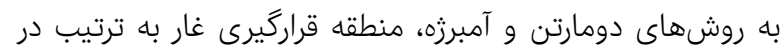

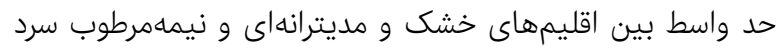

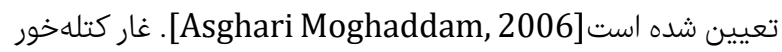

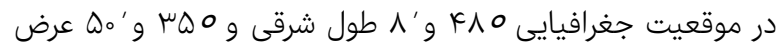

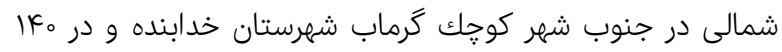
كيلومترى جنوب استان زنجان در شمال غرب ايران قرار گرَفته است.

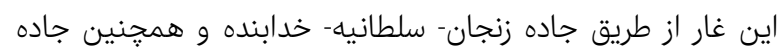

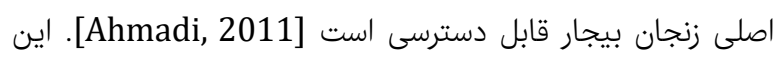

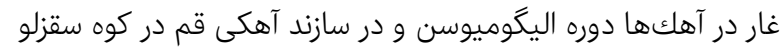

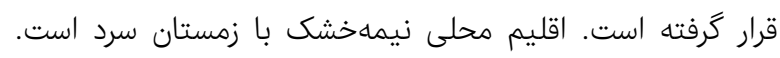

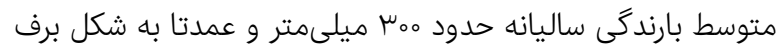

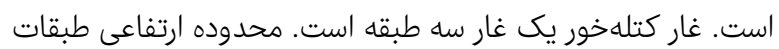

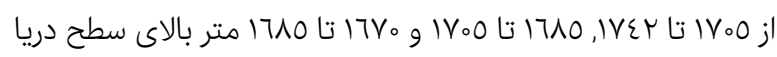
است [Rezaei, 2008] (شكل ().
غارهاى توريستى بايد با تعيين سطح مطلوب يا دامنه شرايط

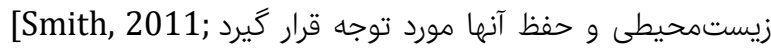

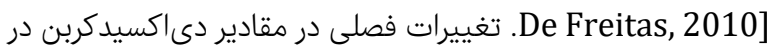

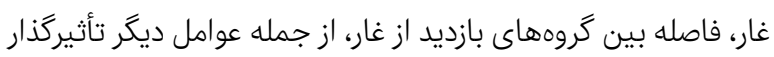

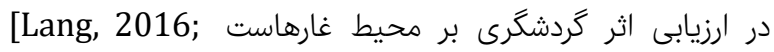

.Lang, 2017]

در اين يزوهش، تلاش داشده است تا با اندازمخيرى دى اكسيدكربن،

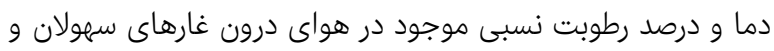

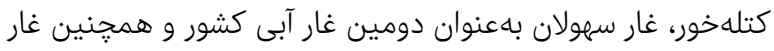

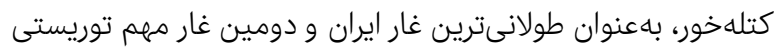

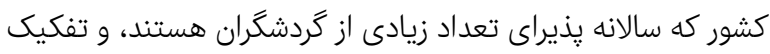

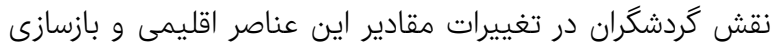

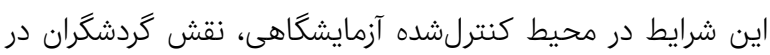

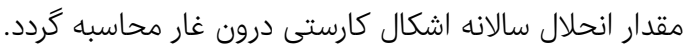

\section{روششناسى}

غار آبى سهولان در جنوب استان آذربايجان غربى و جنوب شرق

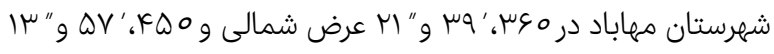
طول شرقى واقع شده است. دسترسى به اين غار از طريق جاده

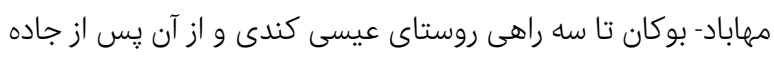

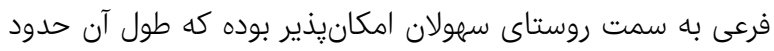

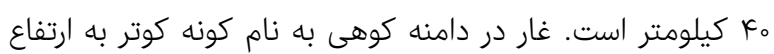

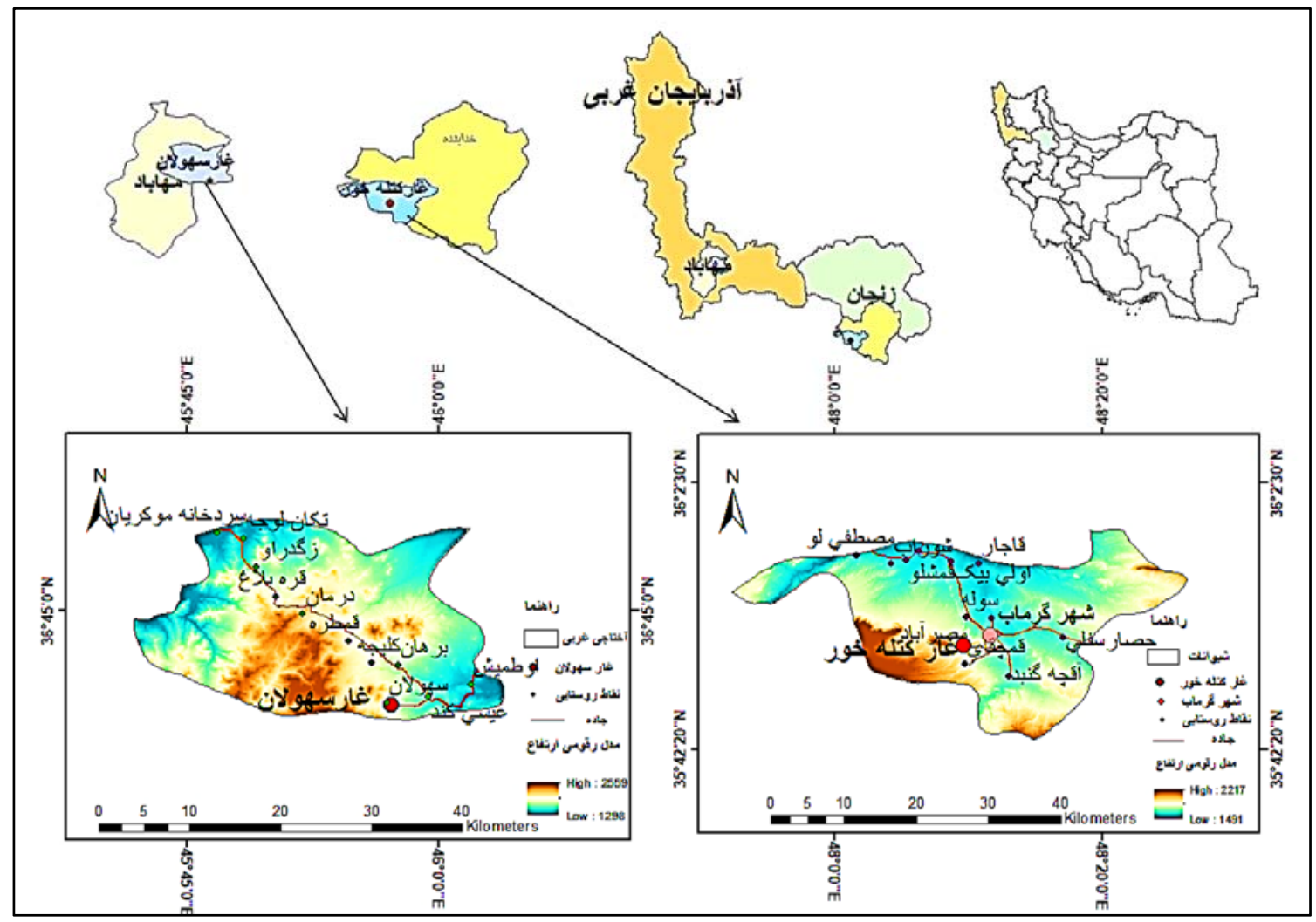

شكل () موقعيت منطقه مورد مطالعه: غار كتلهخور و غار سهولان 
ف ه داود مختارى و همكاران

و تأثير كردشكران در تغييرات مقادير دىاكسيدكربن، درجه حرارت

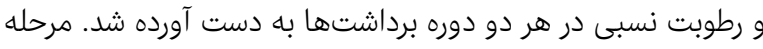

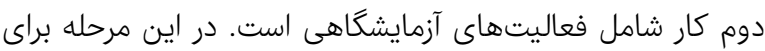

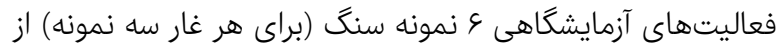

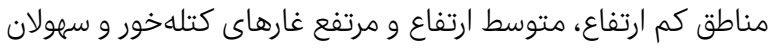

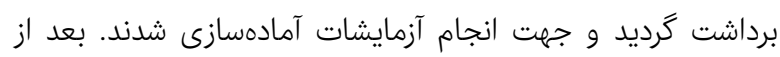

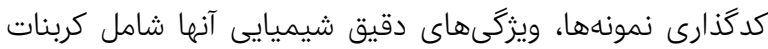

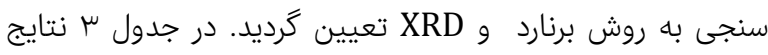
حاصل از آزمايش كربنات سنجى نمونهها ارايه شده است.

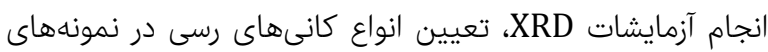

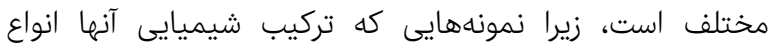

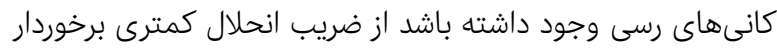

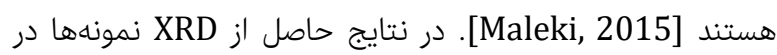

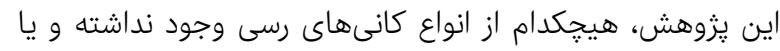

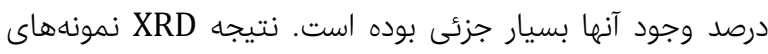

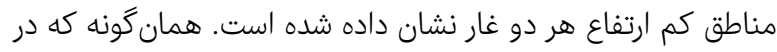
نمودار ا و r ديده مىشود تركيب شيميايى غالب اين نمونه كربنات كلسيم است.

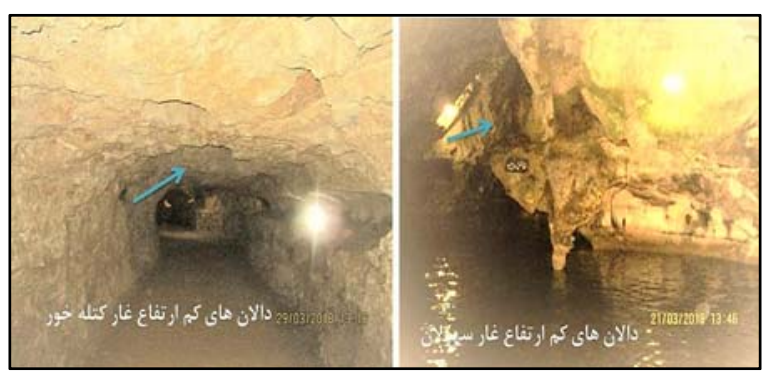

شكل r) تصويرى از دالانهاى كم ارتفاع غار سهولان و كتله خور
فعاليتهاى انجام گرفتته جهت محاسبه مقدار انحلال و نقش

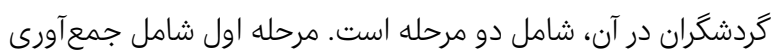

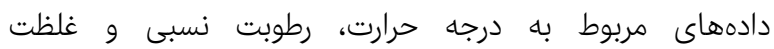

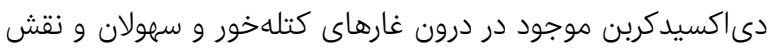

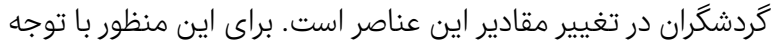

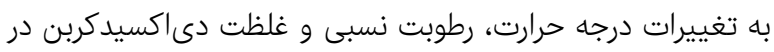

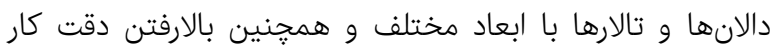
فضاى درون غار به سه بخش منطقه كم ارتفاع (ارتفاع سقف بين الارنا

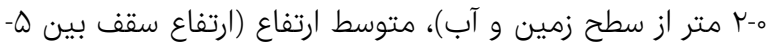

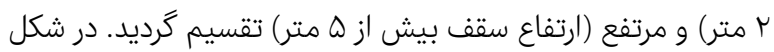

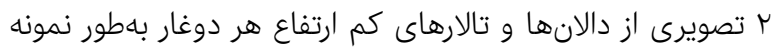

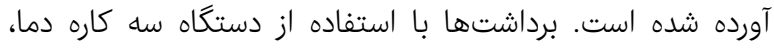

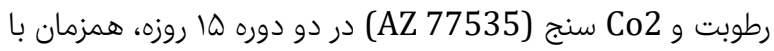
تردد حداقلى كردشكران در درون غارها (غاركتلهخور) و (غار سهولان)

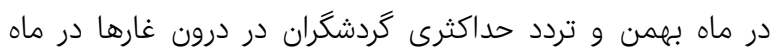

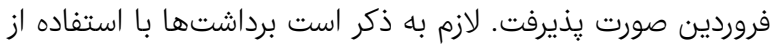

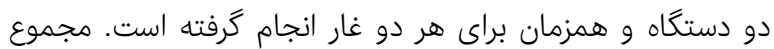

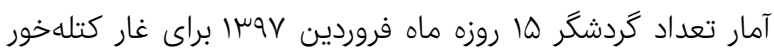

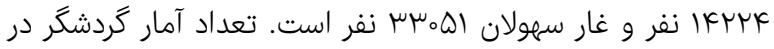

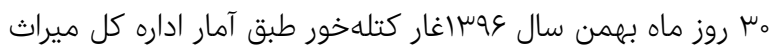

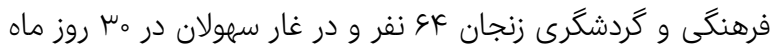

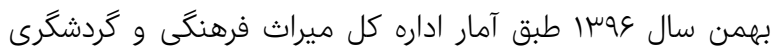

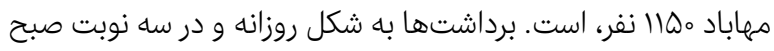
(قبل از ورود كَردشكران)، ظهر و شب (بعد از خروج كَردشكران) در

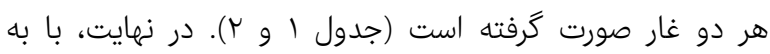

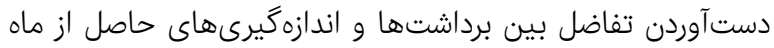

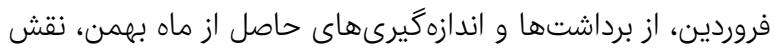

جدول () ميانكَين برداشتهاى دما، رطوبت نسبى و دىاكسيدكربن براى شبيهسازى در شرايط آزمايشگاهى، غار كتلهخور

\begin{tabular}{|c|c|c|c|}
\hline رطوبت نسبى (درصد) & درجه حرارت (C') & دىاكسيدكربن (PPM) & فصل برداشتها \\
\hline १९/৭ & $\mid r / \mu$ & $r \circ 9$ & ميانكين برداشتهاى فصل زمستان \\
\hline $9 \Lambda / 1$ & $10 / \mathrm{V}$ & $110 \mathrm{~V}$ & ميانكين برداشتهاى فصل بهار \\
\hline $99 / \% 0$ & $1 \varepsilon$ & 701 & ميانكين فصول \\
\hline- & - & MIVO & بيشينه دىاكسيدكربن ثبت شده \\
\hline- & - & 178 & كمينه دىاكسيدكربن ثبت شده \\
\hline
\end{tabular}

جدول r) ميانكَين برداشتهاى دما، رطوبت نسبى و دىاكسيدكربن براى شبيهسازى در شرايط آزمايشگاهى، غار سهولان

\begin{tabular}{|c|c|c|c|}
\hline رطوبت نسبى (درصد) & درجه حرارت(c̊) & PPM دئسيدكربن PPM & فصل برداشتها \\
\hline $99 / 9$ & $1 \varepsilon$ & rm & ميانگين برداشتهاى فصل زمستان \\
\hline $97 / 1$ & $10 / \varepsilon$ & $1 \varepsilon \wedge 7$ & ميانكين برداشتهاى فصل بهار \\
\hline Q1/\%० & $1 \varepsilon / V$ & 101 & ميانگين فصول \\
\hline- & - & rYlo & بيشينه دىاكسيدكربن ثبت شده \\
\hline- & - & IVT & كمينه دىاكسيدكربن ثبت شده \\
\hline
\end{tabular}

\begin{tabular}{|c|c|c|c|c|c|c|}
\hline Sch & Scm & Scl & Kch & $\mathrm{Kcm}$ & Kcl & كد نمونهها \\
\hline 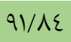 & $9 \varepsilon / \mu_{0}$ & $90 / 94$ & $\wedge \vee / \vee T$ & ८१/१。 & $9 \mu / \Lambda \Lambda$ & درصد كربنات كلسيم \\
\hline
\end{tabular}


هVI شبيهسازى شرايط اقليمى درون غارها در محيط آزمايشكاهى كنترل شده، جهت برآورد مقدار انحلال...

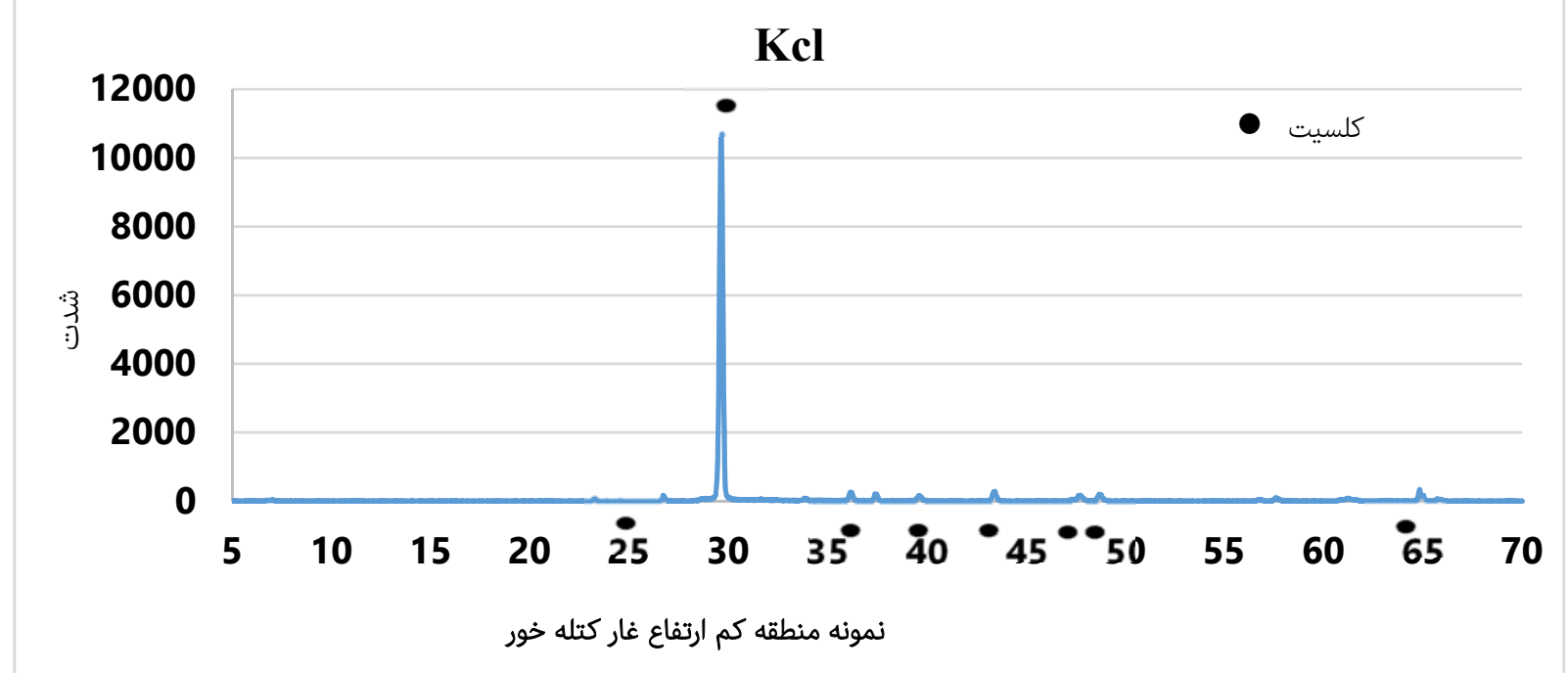

نمودار (1) نمونههاى مناطق كم ارتفاع غار كتله خور

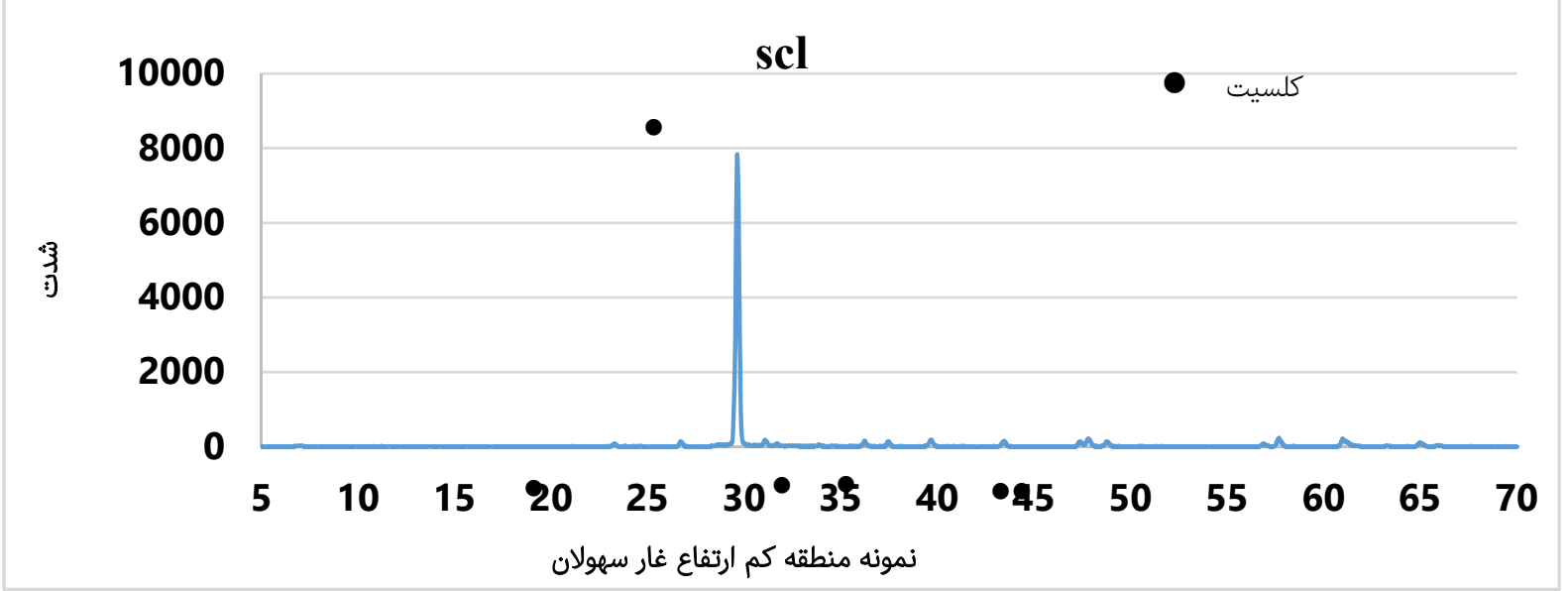

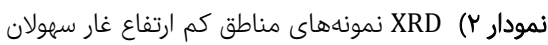

سنگهاى تهييهشده از اشكال كارستى مناطق متوسط ارتفاع و وخره

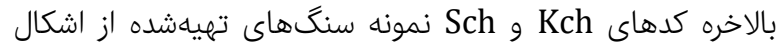
كارستى مناطق مرتفع غار كتلهخور و غار سهولان است.
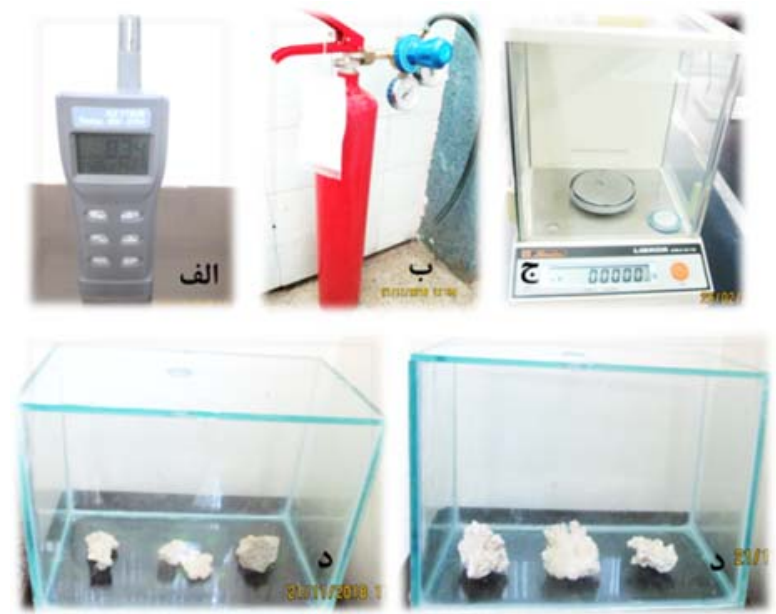

شكل س) تصويرى از محفظههاى شيشهاى و ابزار مورد استفاده در آزمايشكاه
بعد از اين مرحله، فعاليتهاى آزمايشگاهى آغاز شد. به اين ترتيب

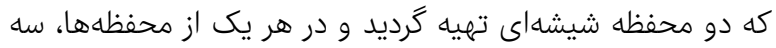

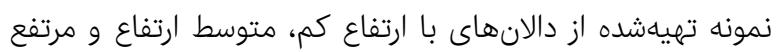

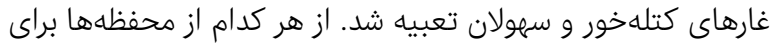
تززيق متوسط دىاكسيدكربن برداشتشده در طى اندازهخيرىهاى نهاى

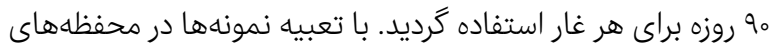

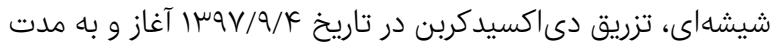

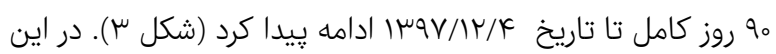
مدت، مقادير دما و درصد رطوبت نسبى برداشتشده از درون درون غارها نيز در داخل محفظههاى شيشهاى كنترل شد. بعد از خروج نمونهها

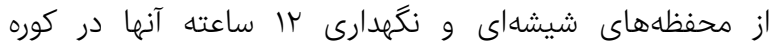

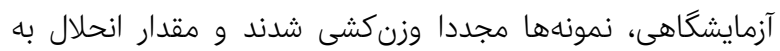
شيوه وزنى به دست آمد. كدهاى Kcl نمونه سنگ تهيهشده از اشكال كارستى مناطق كم

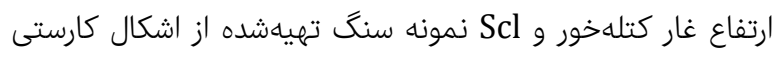

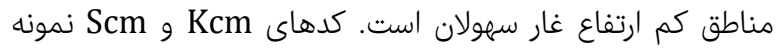


نتايج نهايى مقادير انحلال و يوسته يوسته شدرن إنها نمونهها ابتدا

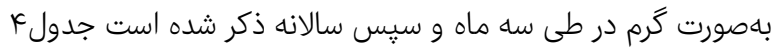

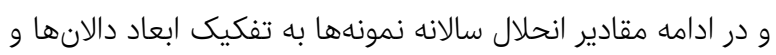
همجنين، تفكيك سهم گَردشكران تشريح شده است.

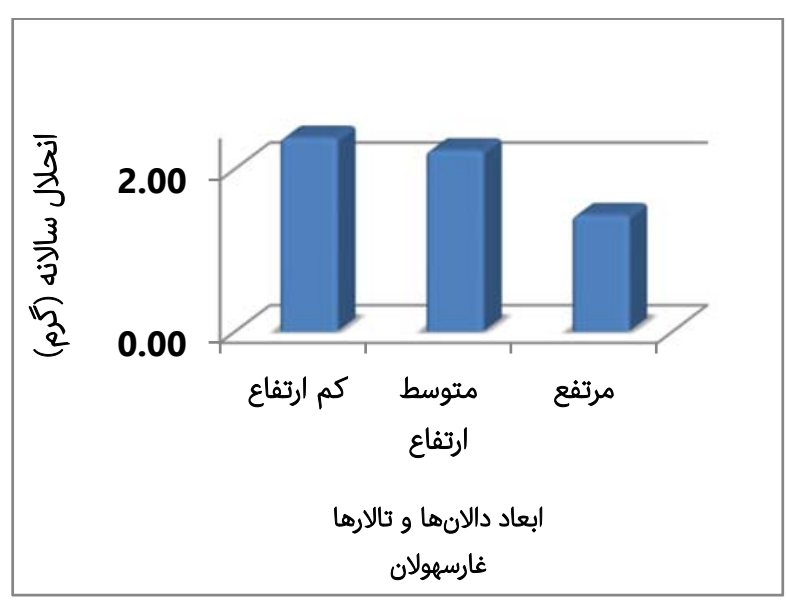

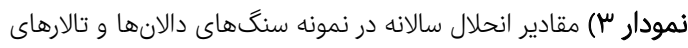

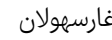

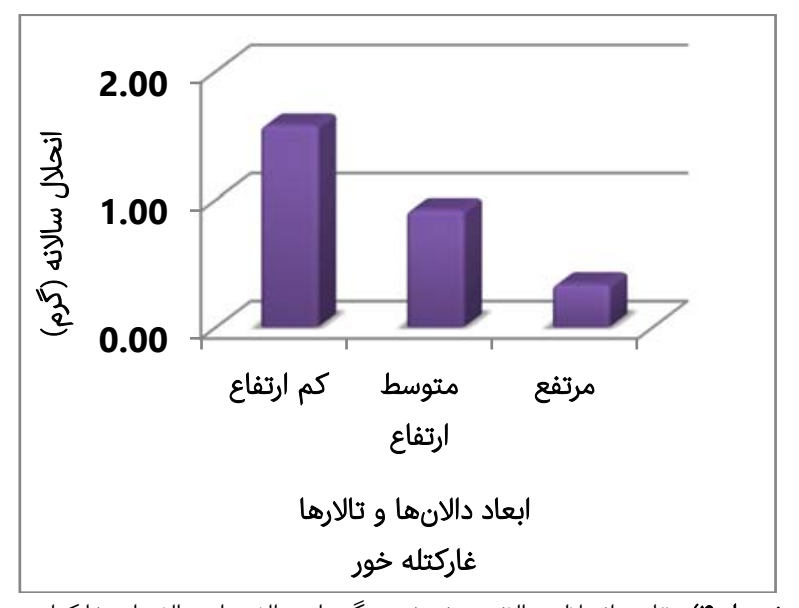

نمودار F) مقادير انحلال سالانه در نمونه سنگهاى دالانها و تالارهاى غاركتله-

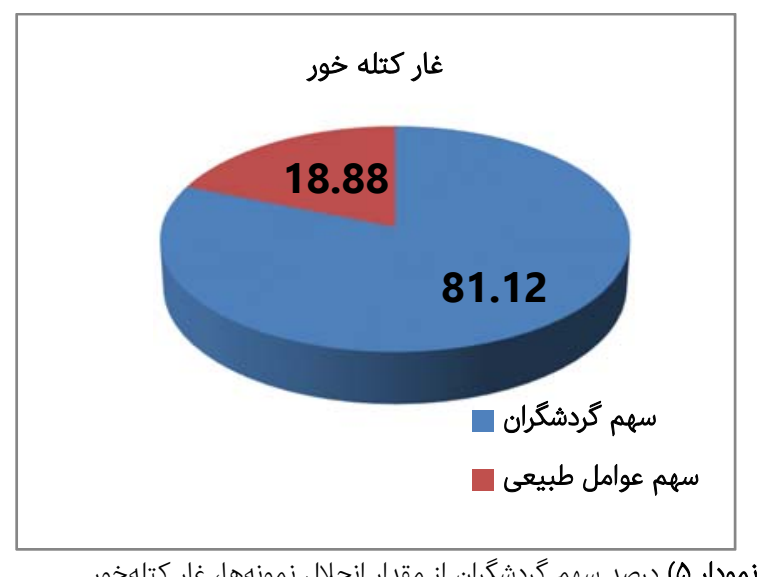

نمودار ه) درصد سهم گَردشكران از مقدار انحلال نمونهها، غار كتلهخور

\begin{tabular}{|c|c|c|c|c|}
\hline 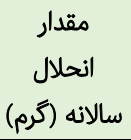 & 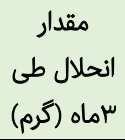 & نمونهها (كرم) & نمونهها (كرم) وزليه & كد نمونهها \\
\hline 1/OV7 & ס/ भq & $\Lambda \mu / 771 \mu$ & $\Lambda \varepsilon / 000 \mu$ & $\begin{array}{c}\text { Kcl } \\
\text { كم ارتفاع كتلهخور) }\end{array}$ \\
\hline o/9r & 列/ & $\varepsilon 9 / \mu \mu 70$ & $\varepsilon 9 / \varepsilon 770$ & $\begin{array}{c}\text { Kcm } \\
\text { كتوسطارتفاع (دالاع } \\
\text { كتلهور) }\end{array}$ \\
\hline o/ $\mu \mu \vee \tau$ & 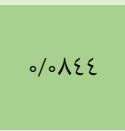 & ION/VAVY & ION/AVMI & $\begin{array}{c}\text { Kch } \\
\text { كتلهان (دالانور) }\end{array}$ \\
\hline$r / \mu \Lambda_{0} \varepsilon \varepsilon$ & ./0901 & ON/VYrq & $09 / \mu / q_{0}$ & $\begin{array}{c}\text { Scl } \\
\text { كمارتفاع سهولانان) }\end{array}$ \\
\hline T/RYEA & ./007r & $10 \Lambda / 700 \varepsilon$ & $109 / \% \circ 77$ & $\begin{array}{c}\text { Scm } \\
\text { متوسطارتفاع (داعلاع) }\end{array}$ \\
\hline $1 / \varepsilon \mu_{\circ} \Lambda$ & o/ruVY & $01 / 99_{0} 1$ & $O Y / \Psi_{\varepsilon} \backslash \Lambda$ & $\begin{array}{c}\text { Sch } \\
\text { (دالانهاى مرتفع سهولان) }\end{array}$ \\
\hline
\end{tabular}

طبق نتايج، بيشترين مقادير انحلال و پوسته يوستهشدن سالانه

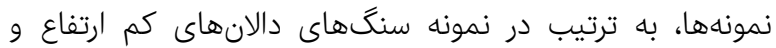

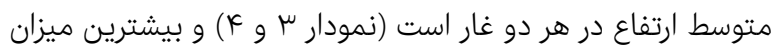

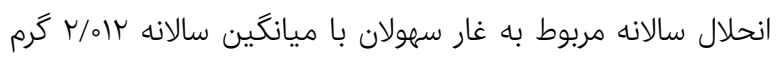

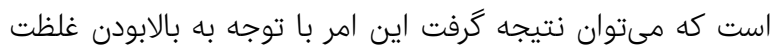

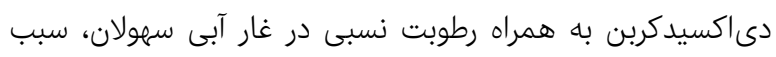

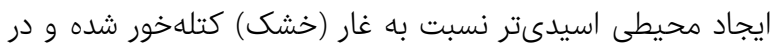

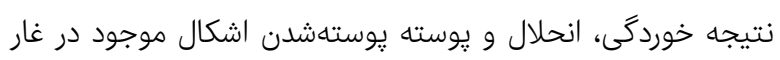

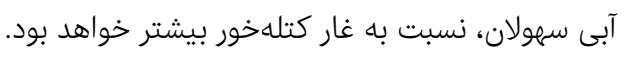
سهم گُدشگران از مقادير انحلال نمونهها مقدار متوسط دى اكسيدكربن ثبتشده از غارهاى سهولان و كتله مخور

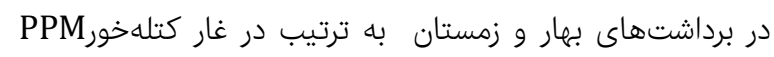

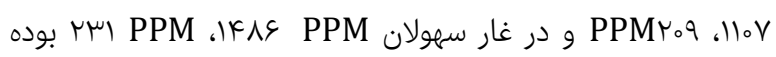
است. با به دستآوردن تفاضل بين متوسط دى اكسيد كربن ثبتشده در بهار و زمستان ارقام

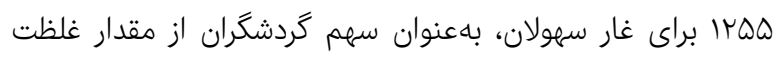
دىاكسيدكربن درون غارهاى كتلهخور و سهولان به دست مى آيد. بر سرد 


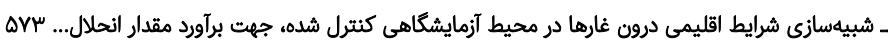

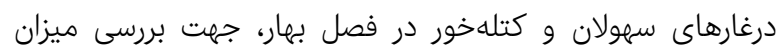

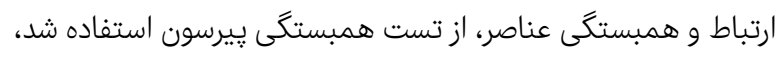
ضريب همبستخى ييرسون، از معيارهاى مورد استفاده در تحليل

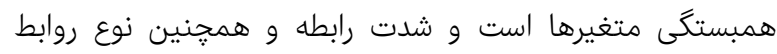

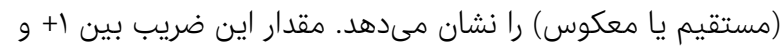

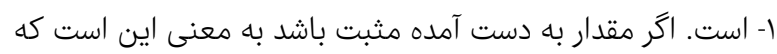

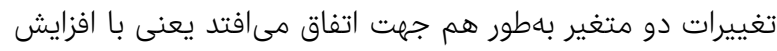

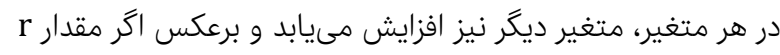

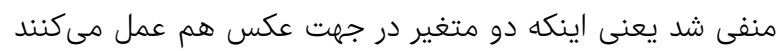

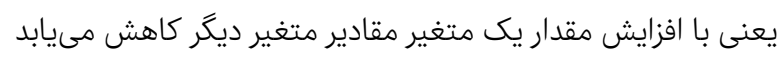

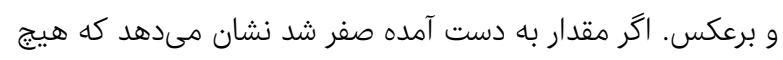

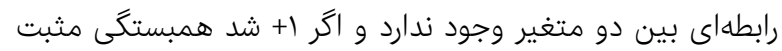

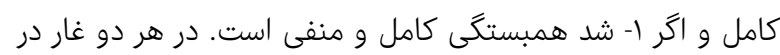

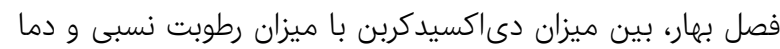

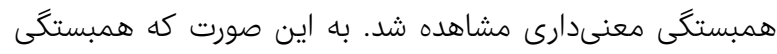

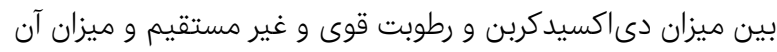

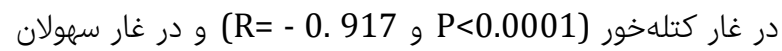

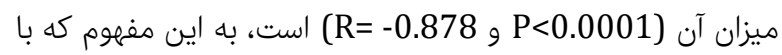

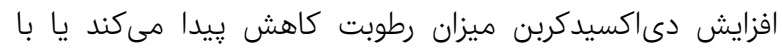

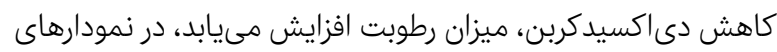

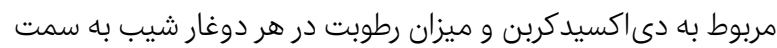

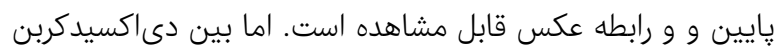

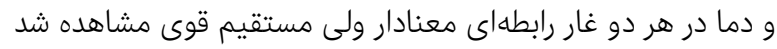

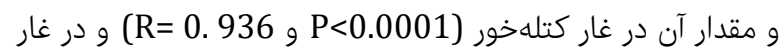

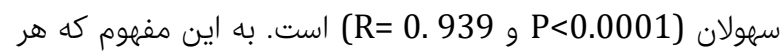
دو با هم افزايش يا كاهش مىيابند، در نمودارهاى مربوط به اله

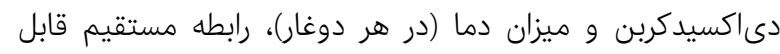

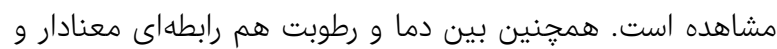
غير مستقيم قوى مشاهده شد، در غار كتلهخور (R) (R=- 0.958 و در غار سهولان (R=0.0001) - 0.951 است، در نمودارهاى مربوط به رطوبت نسبى و ميزان دما (در هر

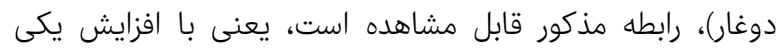

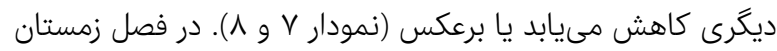

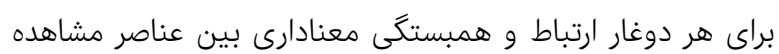

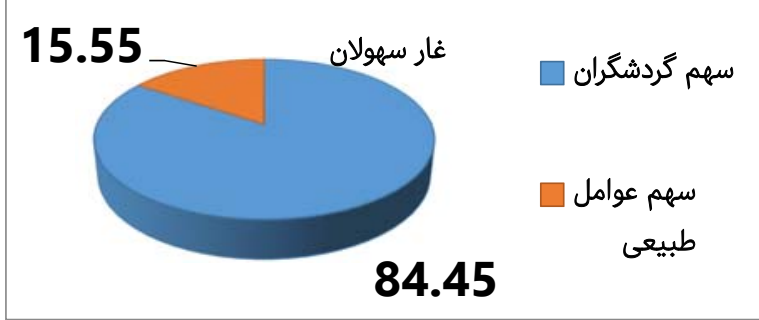

نمودار ع) سهم گَردشكران از مقدار انحلال نمونهها (برحسب درصد)، غار سهولان

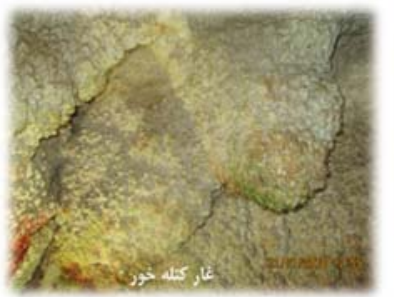

شكل F) خوردگى، تغيير رنگ، روييدن خزه و كاهش شفافيت اشكال كارستى

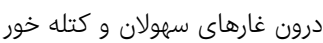

\section{تحليل آمارى دادهها}

براى اطمينان از شيوه عملكرد انحلال تجزيه و تحليل برای داى تمام

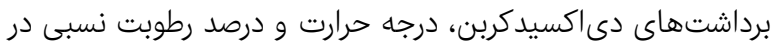

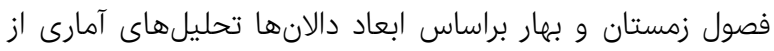

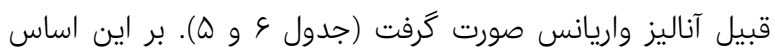

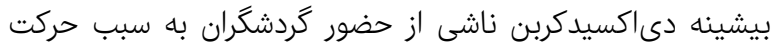

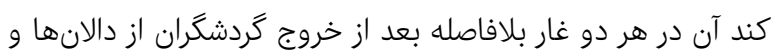

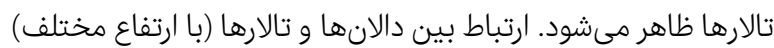

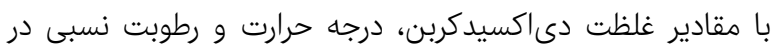

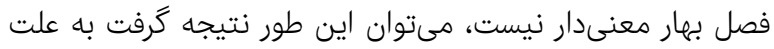

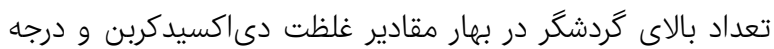
حرارت در تمام فضاى هر دو غار يكسان افزايش يافته است و انحلال

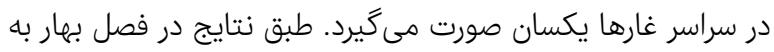

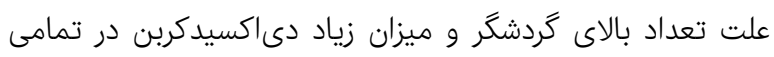

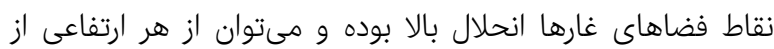

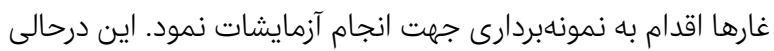
است كه در فصل زمستان ارتباط معنىدارى بين دالانها و تالارها

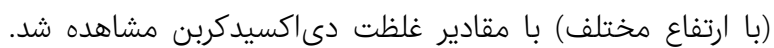

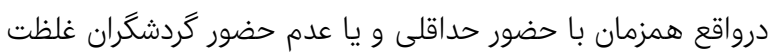
دى اكسيدكربن در دالانها و تالارهاى مختلف غار متفاوت است حدمان.

جدول ه) نتايج آناليز واريانس دىاكسيدكربن، رطوبت نسبى و درجه حرارت براساس ابعاد دالانها غار كتله خور

\begin{tabular}{|c|c|c|c|}
\hline \multicolumn{2}{|l|}{ ابعاد و ارتفاع دالانها } & \multirow{2}{*}{ فصل برداشت } & \multirow{2}{*}{ متغير } \\
\hline آناليز واريانس & سطحمعنى دار & & \\
\hline \multirow{6}{*}{ 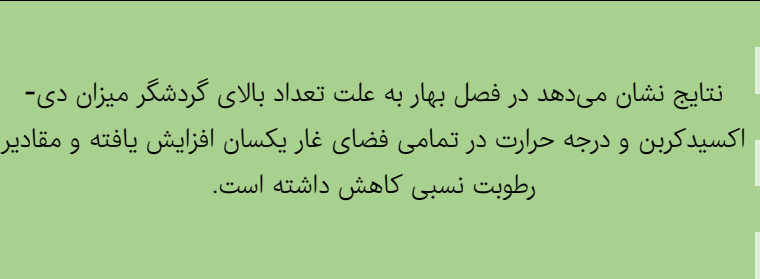 } & o/^но & بهار & دىاكسيدكربن \\
\hline & $\%$ & زمستان & دىاكسيدكربن \\
\hline & $\circ / \varepsilon \circ \varepsilon$ & بهار & رطوبت نسبى \\
\hline & 1 & زمستان & رطوبت نسبى \\
\hline & . & بهار & درجه حرارت \\
\hline & $\%$ & زمستان & درجه حرارت \\
\hline
\end{tabular}


جدول \&) نتايج آناليز واريانس دى اكسيدكران

\begin{tabular}{|c|c|c|c|}
\hline \multicolumn{2}{|c|}{ ابعاد و ارتفاع دالانها } & \multirow{2}{*}{ فصل برداشت } & \multirow{2}{*}{ متغير } \\
\hline آناليز واريانس & سطح معنىدار & & \\
\hline \multirow{6}{*}{ 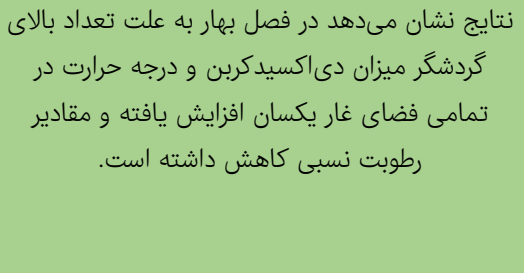 } & ॰/^VT & بهار & دى اكسيدكربن \\
\hline & $\%$ & زمستان & دىاكسيدكربن \\
\hline & 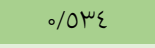 & بهار & رطوبت نسبى \\
\hline & 1 & زمستان & رطوبت نسبى \\
\hline & 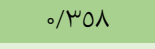 & بهار & درجه حرارت \\
\hline & $\% \% 0$ & زمستان & درجه حرارت \\
\hline
\end{tabular}

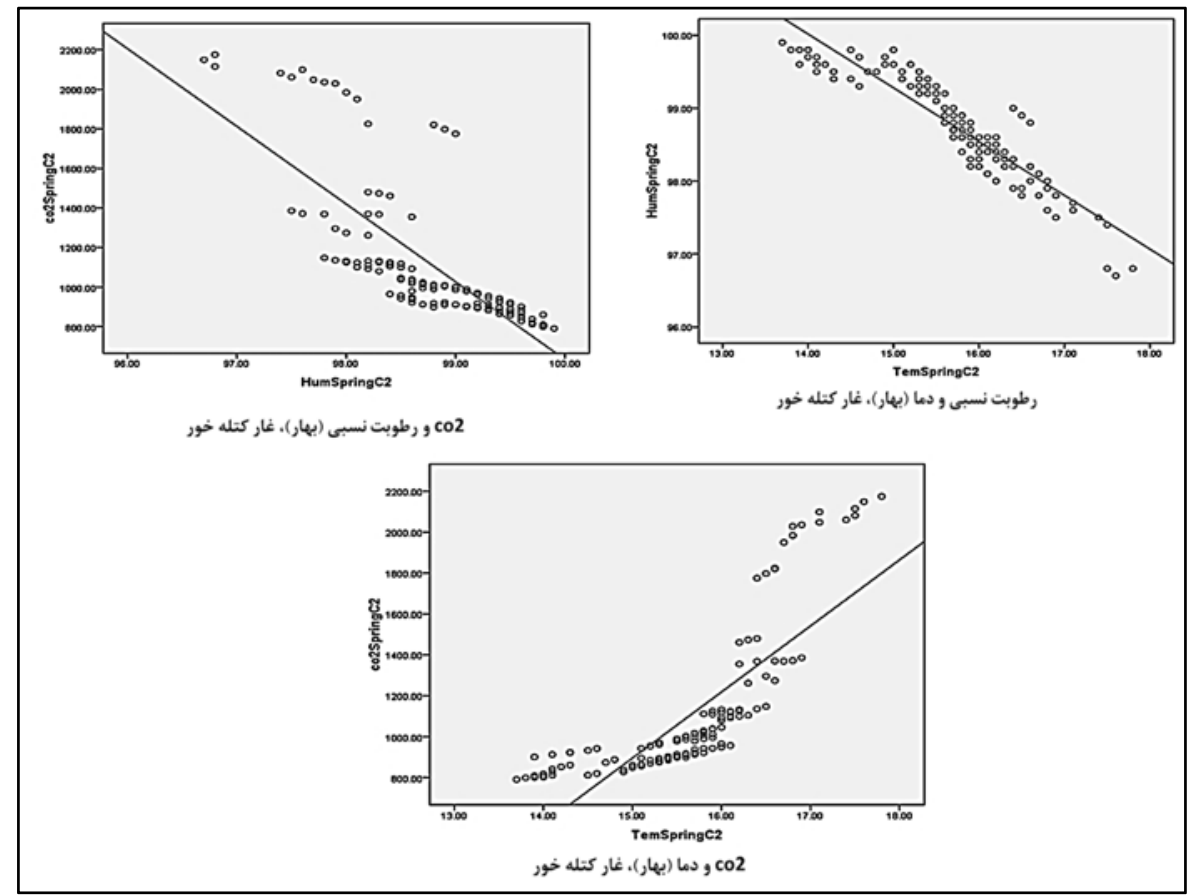

نمودار V) نمودارهاى همبستگى بين عناصر دىاكسيدكربن، دما و رطوبت نسبى غار كتلهخور

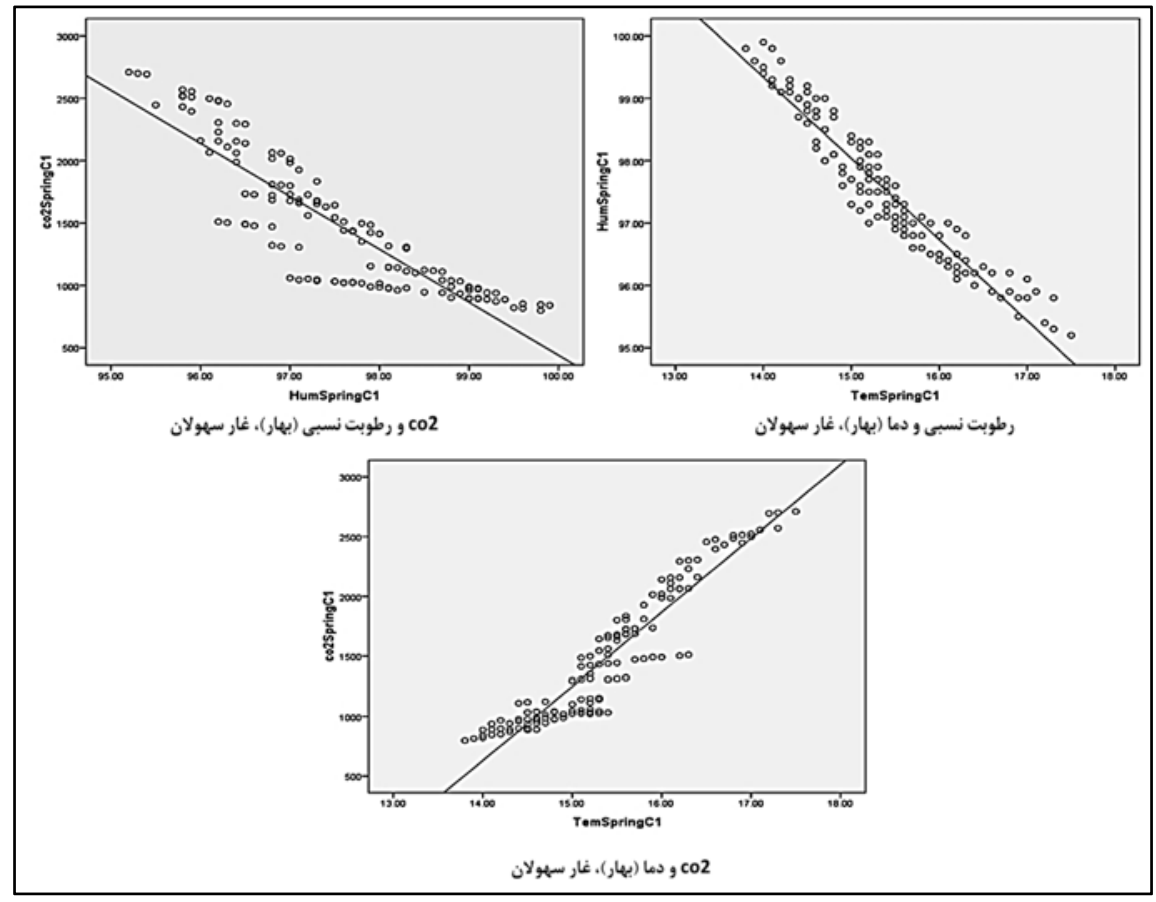

نمودار ^) نمودارهاى همبستخى بين عناصر دىاكسيدكربن، دما و رطوبت نسبى غار سهولان 


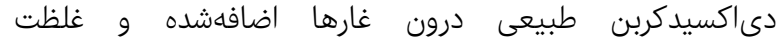

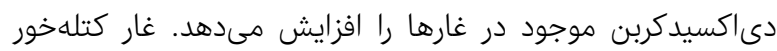
بهنوان طولانىترين غار ايران (ع人ما متر طول) و دومين غار مهم

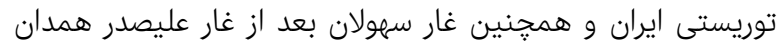

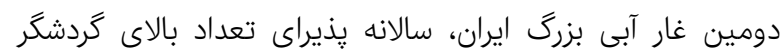

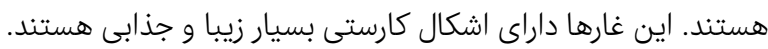

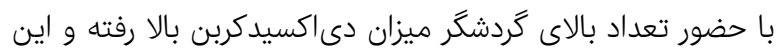

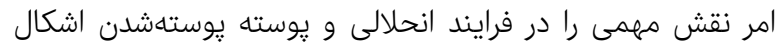

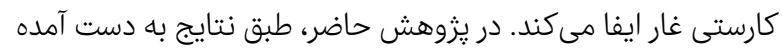

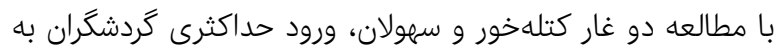

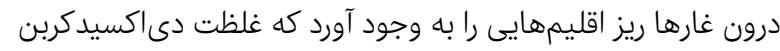

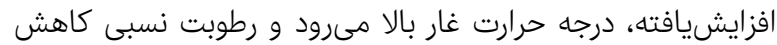

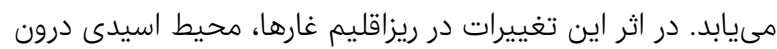

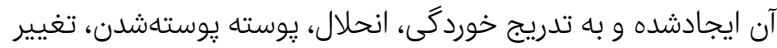

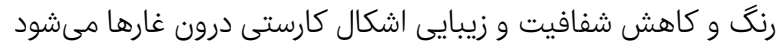

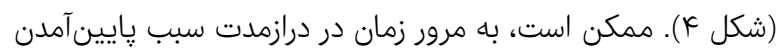
و و از بينرفتن سقف آهكى غار شود. اشكال جالب و جذاب درون

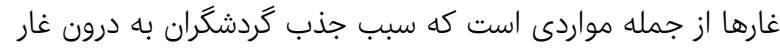

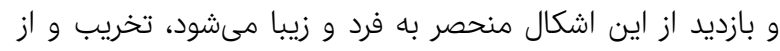

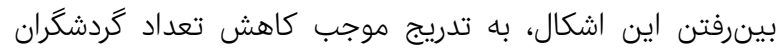

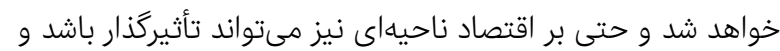

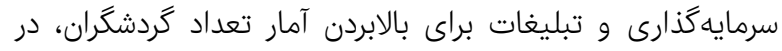
طولانى مدت تأثير منفى دارد.

تشكر و قدرانى: با تشكر از مديريتها و كاركنان محترم، غارهاى سهولان

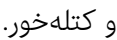
تأييديه اخلاقى: موردى از سوى نويسندكان گزارش نشده است.

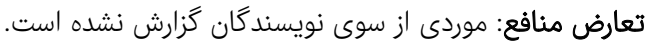

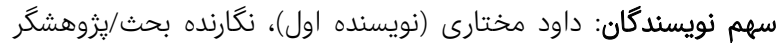

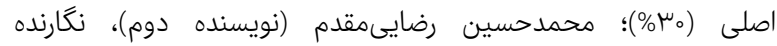

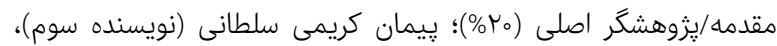

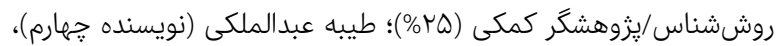

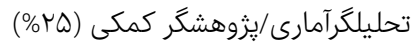

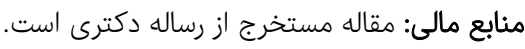

منابع

Ahmadi M, Khoshraftar R (2011). Evaluation of geotourism capabilities of katalekhor cave in Zanjan using the techniques SWOT. Geographical Notion. 5(9):61-74. [Persian]

Asghari Moghaddam A, Moayyed M, Nadiri A (2006). Studying of geomorphology, geology and genesis of Sahoolan water cave northwest of Iran. Journal of Geography and Planning. (22):59-91. [Persian]

Baker AW (2014). The jenolan environmental monitoring program. Proceedings of the Linnean Society of New
در اين يزوهش، جهت برآورد مقدار انحلال و يوسته يوستهشدن سالانه اشكال درون غارهاى كتلهخور و سهولان و برونئ بازسازى شرايط

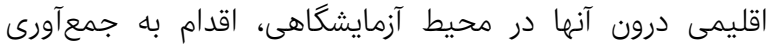

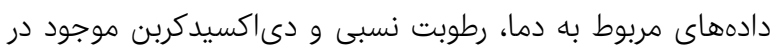

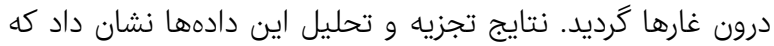
حضور گردشگران باعث افزايش انحلال اشكال كارستى درد هر دو دو غار

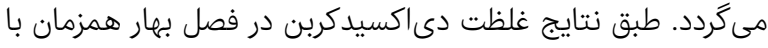

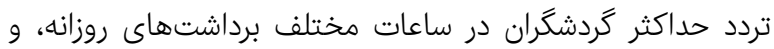

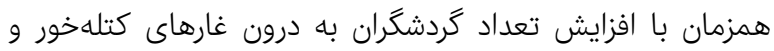
سهولان به تدريج بر غلظت دىاكسيدكربن موجود در درون غارها

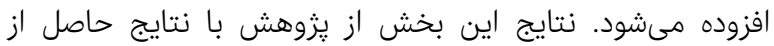

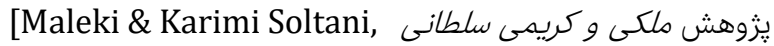

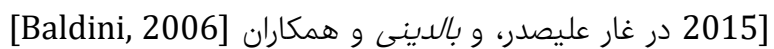

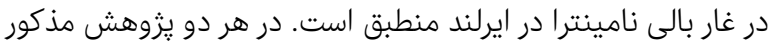

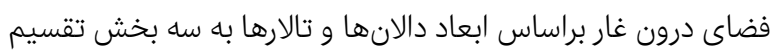

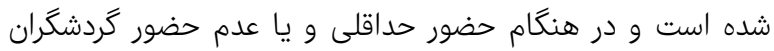

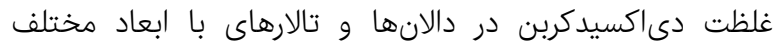

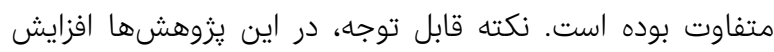

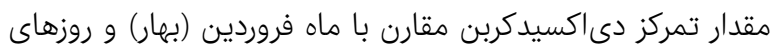

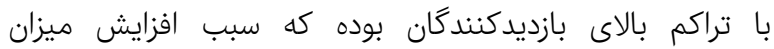
دىاكسيدكربن و افزايش دما و كاهش رطوبت نسبى شده است، برديد

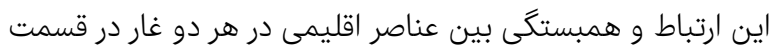

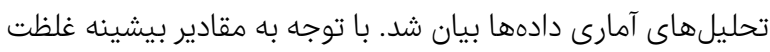

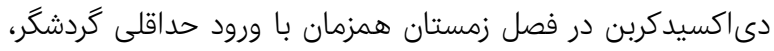

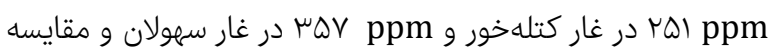
آن با بيشينه غلظت دىاكسيدكربن در فصل بهار همزمان با ورود

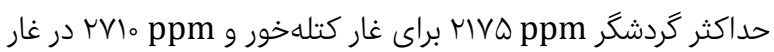

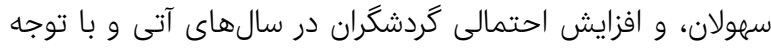

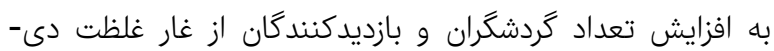

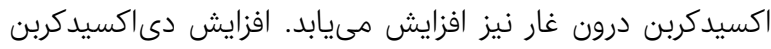

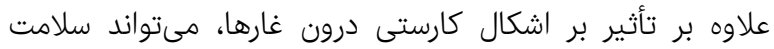

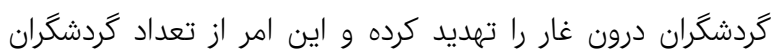

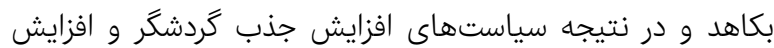

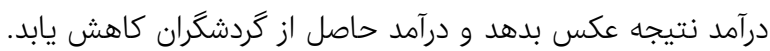

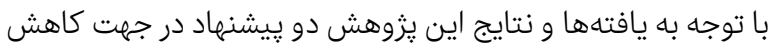

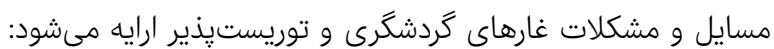

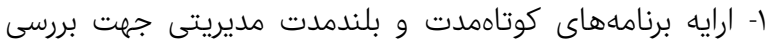

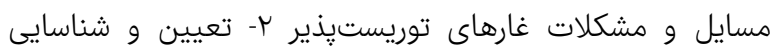

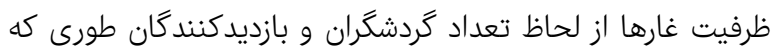
به اكوسيستم و اشكال درون غار زيانى وارد نگردد.

نتيجه

در غارهاى مورد بازديد گردشگَرى، كه روزانه گردشگران زيادى از آنها 
modes and advective fluxes. Theoretical and Applied Climatology. 129(3-4):1355-1372.

Lang M, Faimon J, Pracny' P, Kejíková S (2017). A show cave management: Anthropogenic $\mathrm{CO} 2$ in atmosphere ofV'ypustek cave (Moravian karst, Czech Republic). Journal for Nature Conservation. (35):40-52.

Linan C, Vadilo I, Francisco C (2008). Carbon dioxide concentration air within the Narja cave (Malaga, Andalusia, Spain). International Journal of Speleology. 37(2):99-106.

Maleki A, Ghobadi M, Karimi Soltani P (2015). The role of the tourists in the karst dissoiution of the secondary shapes inside caves, case study: Hamedan Ali-Sadr cave. Geography and environmental sustainability. 5(3):1-15. [Persian]

Maleki A, Karimi Soltani P (2015). Tourists and their role in microclimatic changes inside the caves case study: AliSadr cave (Hamedan, Iran). Journal of Biodiversity and Environmental Sciences. 6(3):535-541.

Maleki A, Karimi Soltani P, Abdolmaleki A (2014). Tourists and their role in microclimatic changes inside the caves case study: Ali-Sadr cave (Hamedan, Iran). The National Conference on Geology and Exploration of Resources. 2015, 11 May: Shiraz. pp. 70-77. [Persian] Michie NA (1997). An investigation of the climate, carbon dioxide and dust in Jenolan caves, N.S.W. [dissertation] Macquarie: Macquarie University.

Mokhtari D (2015). Geotourism. 5th ed. (Vol. 1). Tabriz: Tabriz University Press. [Persian] Moroni M (2013). Radon and carbon dioxide monitoring as approach to touristic exploitation of caves. 5eme colloque national du patrimoine Geologique. 2013, 7-9 May: Tunis. pp. 1-11. [Persian]

Rezaei M, Nakhaei M (2008). Spleogenesis of Katalehkhor cave in Zanjan province. Iranian Journal of Geology. 2(6):11-19. [Persian]

Song L, Wei X, Liang F (2000). The influences of cave tourism on $\mathrm{CO} 2$ and temperature in Baiyun cave, Hebei, China. International Journal of Speleology. 29B (1-4):77
South Wales. (136):19-34.

Baldini JUL, Baldini LM, McDermott F, Clipson N (2006). Carbon dioxide sources, sinks, and spatial variability in Shallow temperate zone caves: Evidence from Ballynamintra cave Irelands. Journal of Cave and Karst Studies. (68):4-11.

Behniyafar A, Qanbarzadeh H (2016). Karst geomorphology: Processes, forms and management of karst environments. (Vol 1). Mashhad: Negaran Sabz. [Persian]

Calaforra JM, Fernández-Cortés A, Sánchez- Martos F, Gisbert J, Pulido-Bosch A (2003). Environmental control for determining human impact and permanent visitor capacity in a potential show cave before tourist use. Environmental Conservation. 30(2):160-16.

De Freitas CR (2010). The role and importance of cave microclimate in the sustainable use and management of show caves. Acta Carsologica. 39(3):477-489.

`Sebela S, Prelov`sek M, Turk J (2013). Impact of peak period visits on the Postojna cave (Slovenia) microclimate. Theoretical and Applied Climatology. 111(1-2):51-64.

Ek C, Gewelt M (1985). Carbon dioxide in cave atmospheres. new result in belgium and comparison with some other countries. Earth Surface Processes and Landforms. 10(2):173-187.

Gillieson D (2005). Caves, processes, development, management. Velayati S, Behniafar A, translator. Mashhad: Sokhan Gostar. [Persian]

Hutacharern C (2004). The effects of human impacts on cave and karst Biodiversity: Thailand Component. Thailand: ARCBC.

Karimi Soltani P, Rezaei K (2015). Daily and monthly fluctuation of carbon dioxide in Ali-Sadr cave of Hamedan and tourists' health. The National Conference on Geology and Exploration of Resources. 2015, 11 March: Shiraz. 3136. [Persian]

Lang M, Faimon J, Godissart J, Ek C (2016). Carbon dioxide seasonality in dynamically ventilated caves: The roles of 